Volume 10. Nomor 2. December 2015
Pandecta
htt//journal.unnes.ac.id/nju/index.php/pandecta

\title{
Kebutuhan Program Continuing Legal Education bagi Mahasiswa Fakultas Hukum
}

\author{
Sartono Sahlan, Suhadi dan Saru Arifin
}

Fakultas Hukum, Universitas Negeri Semarang, Indonesia

Permalink/DOI http://dx.doi.org/10.15294/pandecta.v10i2.

\section{Info Artikel \\ Article History: \\ Received : August 2015; \\ Accepted: September 2015; \\ Published: September 2015}

Keywords:

labour market; student; continued legal education.

\section{Abstrak}

Kompetisi di pasar kerja saat ini menuntut mutu lulusan yang tidak saja memiliki kemampuan akademik yang kuat, melainkan juga alumni yang memiliki nilai tambah khususnya keterampilan di bidang ilmu yang dipelajarinya. Dalam kaitan ini, alumni Fakultas Hukum sejatinya adalah dipersiapkan untuk menjadi professional di bidang hukum, yakni menjadi praktisi hukum yang memiliki kemampuan teoretik yang baik serta keterampilan hukum yang sesuai dengan kebutuhan dunia kerja. Namun sayangnya, model pendidikan hukum yang ada selama ini masih terasa kurang berimbang dikarenakan masih dominan mengajarkan teori-teori hukum saja kepada mahasiswa, sehingga penguatan keterampilan hukum mahasiswa perlu dijembatani dengan penambahan program pendidikan lanjutan. Penelitian ini bertujuan untuk menganalisis alasan-alasan pentingnya program pendidikan hukum lanjutan bagi mahasiswa Fakultas Hukum UNNES; jenis-jenis program pendidikan lanjutan apa saja yang dibutuhkan, serta faktor-faktor pendukung apa saja yang diperlukan. Jenis penelitian ini merupakan penelitian eksplanatif dan juga eksploratif. Hasil penelitian ini menunjukkan bahwa Program Pendidikan lanjutan bagi mahasiswa Fakultas Hukum UNNES dikarenakan porsi teori dalam proses perkuliahan masih sangat dominan. Oleh sebab itu jenis-jenis kebutuhan pendidikan lanjutan yang dibutuhkan mahasiswa adalah pemagangan yang sesuai dengan kebutuhan mahaiswa, training kontrak-kontrak hukum dan legal drafting. Untuk mencapai kesuksesan dalam program pendidikan lanjutan tersebut dibutuhkan proporsi tenaga pengajar dari unsur praktisi yang lebih banyak serta revitalisasi fungsi dan peran laboratorium hukum.

\begin{abstract}
Competition in today's job market demands quality graduates who not only have strong academic skills, but also graduates who have skills in particular added value in the field of science studies. In this regard, the alumni of the Faculty of Law actually are prepared to become professionals in the field of law, such as a legal practitioner who has the theoretical capability as well as legal skills that fit the needs of the working world. Unfortunately, the existing legal education model for this is still noticeably less balanced due to the still dominant legal theories taught only to students, thus strengthening legal skills students need to be bridged by the addition of further education programs. This study aimed to analyze the reasons interests of advanced legal education program for students of the Faculty of Law UNNES; the types of continuing education program of what is needed, as well as factors supporting whatever is needed. This research is an explanatory research and exploratory. Results of this study showed that advanced education program for law students UNNES due to the portion of theory in the lecture are still very dominant. Therefore, the types of continuing education requirements that students need is apprenticeship in accordance with the needs mahaiswa, training contracts and legal drafting laws. To achieve success in the continuing education program required proportion of teachers of the elements that more practitioners and revitalize the functions and role of the legal laboratory.
\end{abstract}

E-mail : sahlan.sartono@yahoo.com 


\section{Pendahuluan}

Era pasar kerja saat ini tidak lagi berorientasi pada gelar akademik dari pencari yang bersangkutan, melainkan pada kualitas yang dimilikinya. Hal itu tergambar jelas dari hasil penelitian yang dilakukan oleh Tony Kurniawan (2015) dari Survey One, sebuah lembaga penelitian pemasaran dengan topik tulisan yang sangat tegas, yakni Menjual Kualitas, Bukan Gelar. Hasil riset tersebut menegaskan bahwa dalam dunia kerja, kualitas menjadi parameter yang menentukan, sementara gelar akademik dan nilai merupakan variable penunjang dalam pertimbangan penilaian seleksi kerja.

Berbicara tentang kualitas lulusan perguruan tinggi, menurut Charlie (2009), ada hubungan yang simetris dengan dukungan fasilitas kampus yang memadai, seleksi penerimaan yang ketat, pengajar yang bermutu, serta metode belajar yang baik. Disamping itu, faktor soft skill mahasiswa menjadi salah satu penentu juga dalam menunjang keberhasilan kerja dari alumni Perguruan Tinggi (Musnandar, 2014). Sementara terkait dengan karakter lulusan, faktor keluarga dna masyarakat dan kehidupan kampus memberikan pengaruh yang signifikan.

Dalam konteks dunia hukum, menurut Yuswanto, alumni Perguruan Tinggi, khususnya fakultas hukum harus memiliki lima kemampuan, yakni: bisa berbicara di pengadilan, bisa merumuskan legal opinion (pendapat hukum), bisa legal drafting (teknik penyusunan peraturan), bisa contract drafting dan bisa bernegosiasi atau alternative dispute resolution. Tanpa memiliki kelima hal tersebut, maka akan sulit bagi alumni Fakultas Hukum untuk bisa diterima di dunia kerja (Hukumonline, 1 Oktober 2014).

Kondisi tersebut dari hasil survei Hukumonline lainnya (2003) terhadap sejumlah Law Firm menunjukkan bahwa FH tidak siap pakai karena hanya menguasai teori. Ketika mereka dihadapkan pada suatu kasus, mereka tidak tahu bagaimana mengaplikasikan teori yang telah mereka dapat untuk memecahkan sebuah kasus. Para lulusan $\mathrm{FH}$ itu juga lemah dalam melakukan analisa. Apalagi, analisa atas suatu kasus yang terdiri dari beberapa aspek hukum yang berbeda-beda. Menurut Dhira Juzar dari Wiriadinata Widyawan, salah satu Law Firm papan atas di Jakarta, sepanjang pengalamannya melakukan rekruitmen, lulusan FH dapat lancar bercerita mengenai isi peraturan perundangan dan teori-teori hukum. Akan tetapi kalau sudah buat dalam kasus, mereka bingung bagaimana harus menerapkan peraturannya. Selanjutnya, Dhira menyebutkan bahwa hal itu disebabkan oleh pola pengajaran di $\mathrm{FH}$ yang teoritis, kurang ke arah praktik, dan tidak merangsang mahasiswa untuk melakukan analisa, melainkan hanya menghapal (Hukumonline, 17 Juli 2003).

Menghadapi realitas tersebut, berbagai Fakultas Hukum di Indonesia berupaya untuk meningkatkan kualitas alumninya melalui berbagai inisiasi program penguatan kompetensi lulusannya, seperti training tambahan, pemagangan dan workshop. Melalui berbagai program tersebut, diharapkan lulusan bisa beradaptasi dengan mudah di dunia kerja.

Dalam kaitan itu, Fakultas Hukum UNNES belum memiliki program pendidikan lanjutan atau tambahan untuk membekali calon alumni dalam memasuki dunia kerja. Selama ini hanya ada tiga program yang memiliki karakteristik yang sama dengan Continuing Legal Education (CLE), yakni: Program Kuliah Lapangan, Pemagangan dan Peradilan Semu. Namun demikian, dari pengakuan alumni seperti Ulhaq dalam sebuah kesempatan diskusi menyatakan bahwa pada awalnya dia kurang percaya diri ketika harus bersaing di dunia kerja dengan berbagai alumni Fakultas Hukum yang sudah mapan dan punya nama. la merasakan bahwa pendidikan yang diterima belum selaras dengan kebutuhan dunia kerja, karena hanya banyak mempelajari teori dan sedikit sekali materi praktek.

Hasil penelitian Sahlan (2013) menunjukkan bahwa pilihan minat profesi pekerjaan dari calon alumni Fakultas Hukum UNNES secara berurutan adalah: Konsultas Hukum/ Advokat, Jaksa, Hakim, dan Legal Officer. Kondisi ini tentu perlu direspon dengan program pendidikan lanjutan untuk memperkuat keterampilan teknis hukum bagi para calon alumni supaya lebih siap kerja.

Berdasarkan deskripsi pada latar bela- 
kang permasalahan tersebut maka dalam tulisan ini akan dianalisis tiga pertanyaan penelitian. Pertama, mengapa program Continuing Legal Education dibutuhkan dalam penguatan kualitas mahasiswa Fakultas Hukum?; Kedua, apa saja jenis-jenis kebutuhan program Continuing Legal Education bagi mahasiswa Fakultas Hukum?; dan Ketiga, apa saja faktorfaktor pendukung yang dibutuhkan dalam penyelenggaraan program Continuing Legal Education bagi mahasiswa Fakultas Hukum?.

\section{Metode Penelitian}

Tipe penelitian yang akan dilakukan ini adalah gabungan antara penelitian eksplanatif dan eksploratif. Pada jenis penelitian ini akan dieksplorasi mengenai faktor-faktor yang berkaitan dengan pertanyaan mengapa calon alumni Fakultas Hukum UNNES memerlukan Program Continuing Legal Education sebagai bekal memasuki dunia kerja. Dalam konteks ini, akan dieksplorasi dari berbagai faktor penyebab, baik dari sisi kurikulum $\mathrm{FH}$, pribadi Mahasiswa sendiri maupun kebutuhan dunia kerja (W.Gulo, 2002:19).

Sementara model penelitian eksploratif digunakan untuk mengeksplorasi jenis-jenis kebutuhan Program Continuing Legal Education yang relevan dengan kondisi pendidikan hukum di FH UNNES dan juga kebutuhan mahasiswa calon alumni dikaitkan juga dengan kebutuhan pasar kerja. Analisis data dilakukan secara deskriptif untuk menghasilkan suatu kesimpulan dan rekomendasi penelitian (Ibrahim, 2006; W.Gulo, 2012).

\section{Hasil Penelitian dan Pembahasan}

Pendidikan di Indonesia berkembang secara beriringan dengan dinamika sosial politik ditingkat nasional. Oleh sebab itu, maka pendidikan hukum di Indonesia bukanlah sebuah proses yang otonom, melainkan suatu proses yang bertuntut secara fungsional mengikuti perkembangan politik, khususnya politik yang bersangkut paut dengan kebijakan dan upaya pemerintah untuk mendagunakan huku untuk meraih tujuan-tujuan yang tak selamanya berada diranah hukum dan/atau keadilan (Sihombing, 2009; Iskandar, 2012; Seran, 1999).
Pada umumnya, menururt Sihombing (2009:4-5), pendidikan hukum dikategorikan ke dalam dua kelompok, yakni: akademis dan profesi. Pendidikan hukum akademis bertujuan untuk memberikan pengetahuan hukum bagi mahasiswa. Pendidikan hukum dengan model akademis ini mengajarkan mahasiswa tentang apa yang dimaksud dengan hukum, apa saja cabang ilmu hukum, siapa yang menjadi subjek dari tia-tiap cabang ilmu hukum, apa prinsip-prinsip yang terkandung dalam hukum dan lain-lain. Dalam konteks ini, maka pendidikan hukum lebih bersifat transfer of knowledge yang bersifat teoretisyang tidak bisa diaplikaiskan secara langsung dalam kehidupan nyata atau praktek hukum.

Adapun pendidikan hukum profesi bertujuan untuk memberikan pemahaman tentang bagaimana menerapkan hukum dengan baik. Diharapkan dengan penddikan hukum profesi, peserta didik memiliki keahlian dalam menerapkan hukum (Juwono, 2003).

Dalam konteks global, pendidikan hukum dibagi dalam dua kelompok, yakni pendidikan hukum profesi yang umumnya dianut dalam system pendidikan hukum di Amerika. Dalam model pendidikan hukum ini, maka sekolah hukum hanya diperuntukkan bagi mereka yang akan berprofesi hukum, sehingga latar belakang pendidikan S1 dari berbagai jurusan terbuka. Sementara pendidikan hukum yang kedua adalah pendidikan hukum yang bersifat umum dan abanyak dianut oleh berbagai Negara. Dalam model pendidikan hukum ini, maka persyaratannya hanya berupa ijazah SMA atau yang sederajat. Dalam konteks ini, maka bentuk pendidikan hukum yang berlangsung adalah pendidikan hukum akademis. Selepas itu, maka bagi alumni yang akan melanjutkan ke jenjang pendidikan hukum profesi harus menempuh jenjang pendidikan profesi hukum lanjutan. Dalam kaitan ini, sistem pendidikan hukum di Indonesia masuk kategori pendidikan hukum akademis (Juwono, 2003; Sihombing, 2009).

Dalam sejarahnya, pendidikan hukum di Indonesia dimulai di Jakarta pada tahun 1942 yang bernama Rechshshoogeschool. Menurut Satjipto Rahardjo (2009), pendidikan hukum pada saat itu diorientasikan 
untuk memajukan kepentingan kolonial Belanda, seperti mengisi kepegawaian Kehakiman, PNS dan pekerjaan bebas. Model pendidikan tersebut menurut Satjipto Rahardjo disebut sebagai colonial based policy, karena hanya dirancang untuk menghasilkan orangorang yang akan mengabdikan struktur dan kepentingan kolonial di Indonesia.

Dalam kondisi seperti itu, pendidikan hukum diajarkan dengan ujuan utama agar para mahasiswa menguasai sejumlah kaidah hukum yang tertuang dalam peraturan perundang-undangan yang harus dipahamimenurut tradisi reine rechslehre kelsenian. Kuliah tersebut juga memodelkan hukum sebagai suatu system normative tertutup yang dalam penggunaannya harus dipandang tidak ada hubungan logis dengan kenyataan empiris yang dialami orang di lapangan (Wignjosoebroto, 2009).

\section{Continuing Legal Education (CLE)}

BusinessDictionary.com (2015), mendefinisikan pengertian continuing education program sebagai sebuah kegiatan perkuliahan formal, kursus, seminar atau hal-hal yang serupa dengan itu yang ditujukan untuk mendidik individu skill tambahan atau pengetahuan yang sifatnya aplikatif atau yang sejalan dengan kebutuhan dunia kerja. Program ini dimaksudkan untuk membekali seseorang keahlian dalam bidang profesi atau pekerjaan tertentu. Kegiatan ini bagi sebagian institusi bersifat opsional, namun bagi lainnya merupakan sebuah kebutuhan untuk memperkuat status personalianya atau dalam konteks ini adalah mahasiswa, atau untuk kebutuhan pemberian sertifikat keahlian atau lisensi tertentu, seperti training Program Khusus Profesi Advokat dan lain sebagainya.

Ada beberapa pilihan tema dalam pendidikan lanjutan ini seperti program bantuan hukum, program pendidikan khusus profesi advokat, hakim, jaksa, atau semacam integrasi nilai-nilai keadilan dalam desain pendidikan huum lanjutan khusus mengenai bantuan hukum. Program-program yang dirancang dalam pendidikan hukum lanjutan ini diseleksi dan dilanjutkan dengan pemagangan untuk menangani kasus-kasus yang ada di masyarakat (Sihombing, 2009).

Dalam sejarhanya, pendidikan lanjutan bermula di Universitas Winconsin Amerika Serikat pada tahun 1907. Praktek CLE di Winconsin tersebut kemudian menjadi role model CLE yang banyak menginspirasi kampus-kampus lainnya di Amerika. Dalam prakteknya, di beberapa kampus di Amerika, CLE ada yang dijalankan secara integral dalam kurikulum Kampus dan sebagian besar lainnya dibuat secara terpisah dan tidak memiliki muatan kredit (SKS). Perkembanganperkembangan selanjutnya dari CLE dilakukan oleh lembaga-lembaga asosiasi profesi, seperti Asosiasi Pengacara (BAR Association) dan asosiasi-asosiasi lainnya sesuai dengan profesi masing-masing (Wikipedia, 2015).

Sementara itu, di Kawasan Asia seperti di Pilipina, CLE dikelola oleh Asosiasi Pengacara, yakni the Integrated BAR of the Philippines (IBP). Melalui CLE yang dikelola oleh IBP tersebut diharapkan, para lawyer yang tergabung didalamnya tetap memiliki komitmen pengetahuan hukum dan selalu berpegang pada kode etik pengacara (Rule 1, Bar Matter No. 850-Supreme Court of the Phillipines).

Dalam konteks Indonesia, program CLE sebagian besar dikelola oleh Laboratorium Fakultas Hukum dan sebagian lagi ada yang berdiri otonom. Namun, yang paling menonjol saat ini adalah Program Khusus Profesi Advokat (PKPA). Hal ini dimulai sejak tahun 2003 seiring dengan disahkannya UU Nomor 18 Tahun 2003 tentang Advokat.

Dalam rangka menyiapkan advokat yang profesional dan memiliki kompetensi di bidang hukum maka sesuai dengan amanat UU Nomor 18 Tahun 2003 setiap calon advokat wajib mengikuti pendidikan khusus profesi advokat yang dilaksanakan oleh organisasi advokat. Undang-Undang Advokat tersebut mengamanatkan bahwa salah satu syarat menjadi Advokat adalah dengan mengikuti pendidikan khusus profesi advokat dan lulus ujian advokat.

Dengan mempertimbangkan bahwa saat ini organisasi advokat bukan lembaga penyelenggara pendidikan sebagaimana dimaksud dalam UU No. 20 Tahun 2003 tentang Sistem Pendidikan Nasional, maka salah satu Organisasi Pendiri PERADI bersama 
dengan lembaga penyelenggara pendidikan dapat menyelenggarakan Pendidikan Khusus Profesi Advokat (PKPA).

Berdasarkan Peraturan Peradi Nomor 3 Tahun 2006 tentang Penyelenggaraan Program Khusus Profesi Advokat dinyatakan bahwa setiap Lembaga Pendidikan (Hukum) yang akan menyelenggarakan PKPA, maka disyaratkan untuk melakukan Kerjasama terlebih dahulu dengan Peradi (Pasal 3). Sedangkan Format Pendidikan Khusus Profesi Advokat (PKPA) dilakukan sebagai berikut:

1. PKPA dilaksanakan dengan masa studi 60 jam

2. Pada masa akhir studi dilakukan evaluasi untuk menilai apakah peserta didik memenuhi syarat untuk mengikuti Ujian Profesi Advokat

3. Bagi yang memenuhi syarat akan diberikan sertifikat dengan status berhak mengikuti ujian profesi advokat

Berdasarkan data penelitian ini terlihat bahwa menjadi praktisi hukum dan Pegawai Negeri Sipil menjadi pilihan karir yang samasama diminati oleh calon alumni Fakultas Hukum, UNNES (27\%). Sementara profesi lain-lain seperti entrepreneur juga menjadi pilihan favorit ketiga dari responden (25\%). Sedangkan legal corporate menjadi pilihan karir keempat (21\%).

Data di atas menunjukkan konsistensinya pilihan karir responden setelah lulus dari Fakultas Hukum, yakni menjadi praktisi hukum dan PNS. Hal ini sejalan dengan penelitian Sahlan (2013) sebelumnya yang menjadikan Konsultan Hukum, Jaksa dan Hakim secara berurut sebagai pilihan karir hukum. Data ini juga sejalan dengan hasil kajian yang dilakukan oleh Hukumonline (2005) bahwa seiring dengan banyaknya pilihan karir menjadi advokat oleh alumni fakultas hukum di berbagai daerah di Indonesia telah memicu tumbuh-suburnya Pendidikan Khusus Profesi Advokat (PKPA). Hal ini juga terjadi di Fakultas Hukum UGM dan Fakultas Hukum UII. Di kedua Fakultas Hukum tersebut, mayoritas mahasiswa memilih Pengacara sebagai pilihan karir hukum setelah lulus dari Fakultas Hukum (Wawancara dengan Sulastri (PD III FH UGM) dan Eko Riyal Nugroho (Pengelola
PKPA FH UII, 10/9/2015 di Kantor masingmasing).

Ekspektasi pilihan karir para responden tersebut, tampaknya masih belum diimbangi dengan rasa percaya diri atas pilihan karir tersebut. Hal ini ditunjukkan oleh data yang menemukan fakta bahwa materi perkuliahan yang selama ini ditempuh di Fakultas Hukum UNNES masih dirasa kurang memadai (49\%) dan $47 \%$ diantaranya menyatakan cukup memadai.

Menurut pandangan responden, kurangnya rasa percaya diri dalam bersaing menggapai karir praktisi hukum tersebut dikarenakan mata kuliah yang diajarkan selama ini di Fakultas Hukum UNNES masih bersifat teoretis (59\%). Selain itu, komposisi tenaga pengajarnya dari kalangan praktisi untuk mata kuliah kemahiran hukum masih sangat sedikit (22\%), dan mata kuliah yang bersifat keterampilan hukum juga dipandang masih minimal (9\%).

Data di atas selaras dengan pernyataan Alumni Fakultas Hukum UNNES, Fransman Tamba (Wawancara, 28/9/2015) yang berkarir menjadi Jaksa sejak tahun 2014 di Kejaksaan Negeri Rantepao, Toraja Utara. Menurut Rasman, semasa kuliah yang bersangkutan menekuni bidang hukum pidana. Untuk mata kuliah ini dia merasa dukungan mata kuliah yang dia pelajari, khususnya pidana cukup memadai dalam mendukung pilihan karirnya tersebut, yakni: Hakim, Jaksa, Penasehat Hukum, dan Legal Coorporate Perusahaan Swasta, dan Jaksa yang sudah didapatkan sebagai karir profesi hukumnya saat ini.

Selain rumpun pidana, menurut catatan Fransman, rumpun mata kuliah lainnya, seperti Perdata dan Tata Usaha Negara masih dipandang belum cukup memadai. Berikut kutipan wawancara peneliti dengan Fransman tersebut selengkapnya:

"Dalam konsentrasi hukum pidana saya rasa cukup. Namun pada bidang perdata dan tata usaha Negara saya rasa masih kurang Imendukungl karena luasnya bidang perdata dan tata usaha Negara, dan sulitnya membentuk kelompok belajar dengan teman-teman". 
Data di atas menunjukkan bahwa kelemahan pada sistem kurikulum Fakultas Hukum, yang banyak menyajikan perkuliahan yang bersifat teoretis dalam bidang kemahiran ilmu hukum, dan juga tenaga pengajar yang masih didominasi dosen dan sedikit praktisi hukum, menjadi alasan utama perlunya program pendidikan lanjutan untuk memenuhi ekspektasi dari para calon alumni Fakultas Hukum UNNES dalam menyiapkan diri menggapai pilihan profesi karir sebagai praktisi hukum di masa yang akan datang.

Kondisi tersebut telah direspon dengan baik oleh Fakultas Hukum UNNES (2015) dengan melakukan penyempurnaan Kurikukulum $\mathrm{FH}$ yang lebih terukur dan mencerminkan kebutuhan riil bagi mahasiswa. Dalam Kurikulum FH 2015 tersebut dinyatakan dengan tegas bahwa lulusan Prodi Hukum adalah menjadi penegak hukum (Polisi, Jaksa, Hakim, dan Pengacara), Legal Drafter, Legal Officer, Konsultan Hukum, Advokasi, dan Peneliti Hukum.

Berdasarkan penelusuran alumni Prodi Hukum S-1 diketahui bahwa lulusan Program Studi Hukum UNNES bekerja di instansi pemerintah maupun swasta. Instansi pemerintah yang dimaksud antara lain POLRI, Kejaksaan, Kehakiman, Badan Pemeriksa Keuangan, Kementerian Keuangan (Kantor Pajak, Bea Cukai), Kementerian Dalam Negeri (Pemerintah Provinsi dan Pemerintah Kota/Kabupaten), Kementerian Hukum dan HAM, Badan Pertanahan Nasional, Kementerian Pertanian, Kementerian Luar Negeri, dan Kementerian Pekerjaan Umum. Instansi swasta antara lain adalah Kantor Pengacara, Kantor Konsultan Hukum, Kantor Notaris, Perbankan, Perusahaan, Lembaga Swadaya Masyarakat, serta organisasi sosial masyarakat lainnya.

Berdasarkan persebaran alumni di masyarakat sebagaimana tersebut di atas, maka Prodi Hukum S-1 memiliki tekad untuk tetap mengedepankan kualitas lulusan guna mempersiapkan mereka dengan bekal yang cukup untuk terjun pada dunia kerja yang diwujudkan dalam penyajian kurikulum berupa matakuliah sesuai dengan kebutuhan pengguna.

Komitmen Fakultas Hukum UNNES tersebut ditegaskan lagi dalam body of know- ledge atau keilmuan dan keahlian yang diselenggarakan oleh Prodi Hukum S-1 UNNES yang mencakup bidang teori dan praktek hukum. Dengan demikian bidang keilmuan dan keahlian yang diselenggarakan menjadi bekal yang memadai untuk meneruskan studi ke strata yang lebih tinggi (S-2) atau menjadi tenaga profesional di bidang hukum. Guna mewujudkan tujuan tersebut bahan kajian pembelajaran dalam Prodi Hukum S-1 UNNES terdiri dari Inti Keilmuan, IPTEKS Pendukung, IPTEKS Pelengkap, IPTEKS yang dikembangkan dan Penciri UNNES. Bidang keilmuan dan keahlian tersebut terdiri atas bidang Hukum Pidana, Hukum Perdata, Hukum Tata Negara, Hukum Administrasi Negara, Hukum Agraria dan Lingkungan, serta Hukum dan Masyarakat. Bidang hukum tersebut merupakan pilihan bagi para mahasiswa sesuai dengan bakat dan minat masingmasing.

Data body of knowledge Prodi S-1 FH UNNES tersebut menunjukkan klasifikasi rumpun mata kuliah antara yang inti keilmuan dengan IPTEKS pendukung, pengembangan, pelengkap dan kekhasan. Namun sayangnya, mata kuliah kemahiran atau keterampilan hukum dalam skema di atas, hanya dikategorikan sebagai kelompok mata kuliah IPTEKS Pendukung, seperti: teori dan praktek advokasi, teori dan praktek non litigasi, teori dan praktek perancangan kontrak, Hukum dan HAM yang progresif, Praktik dan Pendampingan Masyarakat serta pembangunan karakter bangsa. Hal ini menunjukkan adanya inkonsisten antara tujuan dari kurikulum dengan proses perkuliahan yang, serta dengan ekspektasi mahasiswa yang menjadikan profesi praktisi hukum sebagai pilihan karir setelah lulus dari Fakultas Hukum UNNES.

Kondisi tersebut sedikit tertutupi dengan adanya peran Laboratorium Hukum sebagaimana disampaikan responden yang menunjukkan bahwa keberadaan Laboratorium Hukum dalam menunjang skill hukum mahasiswa seperti Peradilan Semu, PKBH dan Pemagangan dianggap responden sudah memadai (58\%). Meskipun demikian, terdapat sebanyak 39\% responden yang menyatakan kurang memadai, dan sisanya menyatakan tidak memadai sebanyak (3\%). 
Bagi responden yang menjawab kurang dan/atau tidak memadainya keberadaan Laboratorium Hukum dalam mendukung skill mahasiswa, dikarenakan program-program yang dilakukan Laboratorium $\mathrm{FH}$, kurang bervariasi dan menoton (40\%). Selain itu, pelayanan kepada mahasiswa juga dianggap kurang memadai (40\%), dan SDM Pengelolanya yang dianggap masih kurang (21\%).

Sejatinya, Laborarium Hukum dibuat sebagai sarana menempa skill mahasiswa yang tidak diajarkan dalam kelas perkuliahan reguler. Oleh sebab itu, maka keberadaan Laboratorium Hukum sangatlah strategis dalam mendukung skill hukum mahasiswa. Hal ini yang menjadi bukti dari keberhasilan sebagian besar alumni FH UII dalam karir sebagai praktisi Hukum (Wawancara dengan Eko Riyal Nugoro, 10/9/2015 di FH UII Yogyakarta).

Berdasarkan Company Profile Pusdiklat Laboratorium Fakultas Hukum UII (2009) dijelaskan bahwa untuk mengantisipasi era global yang ditandai dengan perkembangan informasi dan teknologi, maka tuntutan sumber daya manusia yang handal khususnya di bidang hukum, menjadi sebuah keniscayaan. Oleh sebab itu, Fakultas Hukum UII melalui laboratoriumnya berusaha mengantisipasi dan merespon fenomena globalisasi tersebut melalui program-program pelatihan guna membekali mahasiswanya di bidang keterampilan hukum, sehingga mereka dapat berdaya saing tinggi di pasar kerja dan dapat menciptakan lapangan kerja.

Secara teknis Laboratorium Fakultas Hukum Universitas Islam Indonesia mempunyai 2 (dua) Pusat, yaitu: Pusat Konsultasi dan Bantuan Hukum (PKBH) dan Pusat Pendidikan dan Latihan (Pusdiklat) yang masingmasing dipimpin oleh seorang Kepala Pusat dengan tugas dan wewenang yang berbeda. Pusdiklat memiliki tanggungjawab untuk membuat kebijakan penyusunan dan pelaksanaan program kerja di bidang pendidikan kemahiran hukum dan pelatihan hukum bagi mahasiswa dan masyarakat, mengatur, mengelola dan mengembangkan mata kuliah kemahiran hukum (MKKH), melakukan kegiatan pengembangan kurikulum, silabus dan satuan acara perkuliahan (SAP) Mata Kuliah
Kemahiran Hukum (MKKH), bertanggungjawab terhadap pengelolaan dan pengembangan pusdiklat.

Data tersebut menujukkan bahwa eksistensi laboratorium Fakultas Hukum Universitas Islam Indonesia diposisikan secara strategis dalam mengembangkan skill hukum mahasiswa dalam menyiapkan diri mereka memasuki dunia kerja setelah lulus dari Fakultas Hukum. Satu hal yang menarik lainnya adalah bahwa Pusdiklat yang berada di bawah naungan laboratorium tersebut memiliki kewenangan untuk mengkaji dan mengembangkan mata kuliah kemahiran hukum. Hal ini menunjukkan bahwa keberadaan Pusdiklat Hukum UII diberikan kewenangan otonomis yang sangat strategis dalam merespon dinamika dan perkembangan kebutuhan pasar tenaga kerja di bidang hukum.

Kondisi tersebut juga menunjukkan pentingnya penguatan fungsi dan peran dari laboratorium hukum. Hal ini mengingat waktu pendidikan hukum hanya empat tahun yang tidak mungkin dapat memberikan semua basic knowledge mengenai hukum dan legal culture. Apalagi, corporate culture untuk masing-masing profesi. Jumlah 144 SKS saja, masih banyak pengajar yang merasa bahwa waktu yang diberikan belumlah cukup untuk memberikan keseluruhan materi kuliah pada mahasiswa.

Komponen perkuliahan yang dituntut memang terdiri dari tiga, yakni doktrin, hukum positif, dan kasus. Diharapkan, dengan basic legal knowledge semacam ini, para lulusan kelak akan dapat mengembangkan sendiri kemahiran dan keterampilan mereka di bidang yang mereka tekuni setelah lulus. Harapan ini nampaknya belum dapat terpenuhi, seperti tercermin dari banyaknya keluhan mengani lulusan fakultas hukum.

Keluhan yang disampaikan oleh para konsumen yang memanfaatkan lulusan fakultas hukum, umumnya berkisar sekitar keterbatasan lulusan tersebut untuk langsung dapat bekerja dalam suatu lembaga. Keterampilan hukum yang diharapkan nampak belum dapat dipenuhi melalui pendidikan hukum. Kondisi semacam ini harus dipahami apabila para konsumen tersebut menuntut adanya lulusan yang 'siap pakai,' dan bukan- 
nya 'siap kerja.' Bahwasanya sarjana hukum banyak yang tidak memahami secara mendalam akan hukum acara, pada dasarnya merupakan suatu hal yang tidak dapat dilepaskan dari pengembangan kurikulum yang terjadi. Apalagi, ditambah dengan pengharapan para dosen bahwa lulusan mereka akan dapat lebih banyak belajar di luar.

Banyak sarjana hukum senior yang mengharapkan bahwa the new recruts mengerti mengenai hukum seperti mereka dulu. Satu hal yang dilupakan adalah bahwa kurikulum pendidikan tinggi sebelum tahun 1983 berbeda dengan setelah tahun tersebut melalui Surat Keputusan Direktur Jenderal Pendidikan Tinggi No. 30 tahun 1983. Hal ini tentu saja membawa perubahan pula dalam kurikulum yang tadinya mengacu pada sistem semester menjadi Sistem Satuan Kredit Semester (SKS). Dengan sistem semester, setiap mata kuliah pokok diberikan selama satu tahun. Sedang dalam sistem SKS, mata kuliah Hukum Acara Pidana misalnya, hanya tiga jam seminggu selama satu semester (3 SKS). Selain itu, mata kuliah yang diberikan pada mahasiswa jauh berubah jumlahnya dan juga variasinya.

Keputusan Menteri Pendidikan dan Kebudayaan No. 017/D/0/1993 mengenai kurikulum fakultas hukum yang diubah dengan SK Mendikbud No. 0325/U/1994 merupakan suatu upaya mengadakan reorientasi dalam pendidikan hukum. Keputusan mengenai kurikulum ini, antara lain diambil karena tingginya tingkat keluhan konsumen terhadap lulusan fakultas hukum yang mereka sebut sebagai 'tidak memperhatikan kebutuhan pasar'. Sebab itu pulalah dalam kurikulum ini dimasukkan satu kelompok mata kuliah yang disebut sebagai 'Pendidikan dan Latihan Kemahiran Hukum'.

Upaya untuk mendekatkan pendidikan hukum dengan profesi hukum ini disambut gembira oleh semua pihak tentunya. Apalagi, bila melihat tujuan program studi ilmu hukum yakni menyiapkan peserta didik menjadi sarjana hukum yang:

a. menguasai hukum Indonesia,

b. menguasai dasar ilmiah dan dasar kemahiran kerja untuk mengembangkan ilmu hukum dan hukum,

c. mengenal dan peka terhadap masalah keadilan dan masalah kemasyarakatan,

d. mampu menganalisis hukum dalam masyarakat,

e. mampu menggunakan hukum sebagai sarana untuk memecahkan masalah kemasyarakatan dengan bijaksana dan berdasarkan atas prinsip hukum.

Harus diakui bahwa beban fakultas hukum sangatlah tidak ringan untuk memikul beban seperti di atas. Harapan masyarakat untuk mendapat sarjana hukum yang terampil menggunakan hukum untuk menyelesaikan masalah (problem solving) belum juga terpenuhi karena berbagai alasan, baik internal maupun eksternal seperti disebutkan di atas. Oleh sebab itu, pendidikan hukum lanjutan yang dimotori oleh laboratorium hukum merupakan langkah yang strtaegis untuk dilakukan guna menjembatani kesenjangan antara proses pendidikan perkuliahan dengan kebutuhan tenaga kerja hukum yang terampil.

\section{Analisis Jenis-Jenis Kebutuhan CLE}

Hasil survei terhadap responden penelitian ini mengenai jenis-jenis program penguatan skill mahasiswa dalam bidang hukum yang mencakup empat hal, yakni: Training Kontrak Bisnis; Training Legal Drafting; Pendidikan Khusus Profesi Advokat; dan Pemagangan sebagaimana terlihat pada Gambar 1. menunjukkan bahwa pemagangan menjadi pilihan utama (39\%) diikuti secara berurutan dengan training legal drafting (34\%), training kontrak bisnis (15\%) dan sisanya PKPA (12\%).

Data di atas menunjukkan bahwa porsi pemagangan dipersepsi positif dan memberikan banyak pengalaman bagi calon alumni Fakultas Huum UNNES. Dalam konteks pendidikan lanjutan, pemagangan merupakan salah satu metode yang strategis untuk mengenalkan mahasiswa kepada dunia kerja.

Tujuan Magang bagi mahasiswa adalah untuk melatih mahasiswa mengenal dunia praktek hukum sehingga diharapkan dapat meningkatkan wawasan dan kemampuan 
softskill (kognitif, afektif dan psikomotorik) mahasiswa dalam memahami keilmuan hukum baik pada tataran teoritis maupun praktis. sebagai berikut:

1. Secara kognitif, Magang bertujuan untuk melatih melatih kepekaan mahasiswa dalam dunia kerja praktek hukum dan memberikan pengalaman kerja di bidang keahlian hukum.

2. Secara afektif, Mahasiswa dapat menerapkan etika dan tanggung jawab keilmuan hukum dalam dunia kerja praktek hukum.

3. Secara psikomotorik, mahasiswa dapat mengembangkan kreatifitas ide dalam dunia kerja praktek hukum dan terampil untuk memberikan gambaran solusi hukum terhadap permasalahan praktis yang terjadi.

Hal itu selaras dengan pandangan yang menyatakan bahwa kompetensi dan kualitas seorang mahasiswa ditentukan oleh banyak faktor dan variabel. Pengalaman bisa menjadi kunci tersendiri bagi mahasiswa dalam meraih kesuksesan itu, Dewasa ini pengalaman dalam wujud kompetensi diwujudkan dengan magang, semacam bekerja pada sebuah instansi, baik negeri maupun swasta. Teorisasi dari awal masuk kuliah bisa secara langsung dipraktekan di lapangan oleh mahasiswa. Oleh sebab itu, keberadaan magang menjadi hal yang cukup positif baik secara ekonomi dan pengalaman kerja sekaligus wawasan mereka. Selain itu, magang juga dapat meningkatkan kemampuan mahasiswa dalam bidang yang mereka ambil, dengan syarat magang yang diambil sesuai ilmu mereka.

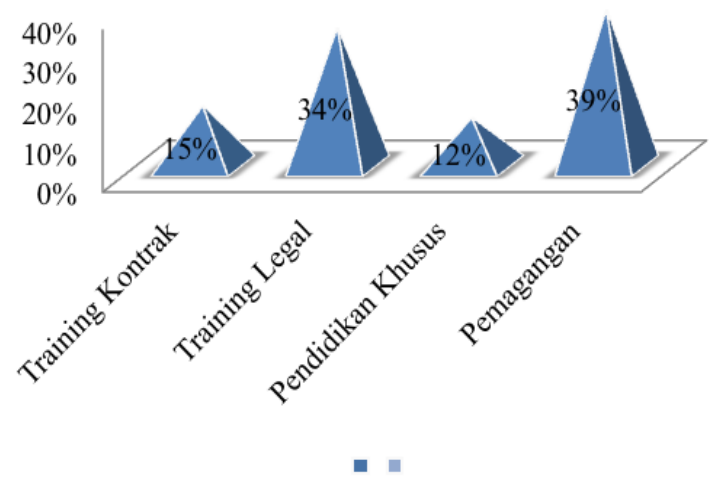

Gambar 1. Jenis-Jenis Kebutuhan Program CLE
Namun demikian, dalam skema CLE pemagangan didesain sebagai rangkaian akhir dari proses pengayaan skill mahasiswa di laboratorium hukum, dengan membekali mahasiswa keterampilan teknis dalam pembuatan dokumen-dokumen hukum, keterampilan litigasi, legal officer dan lain sebagainya, sehingga ketika mereka diterjunkan dalam pemagangan memiliki dasar-dasar keterampilan dan pengetahuan dibidang teknis pekerjaan.

Di Indonesia, program CLE sebagian besar dikelola oleh Laboratorium Fakultas Hukum dan sebagian lagi ada yang berdiri otonom. Namun, yang paling menonjol saat ini adalah Program Khusus Profesi Advokat (PKPA). Hal ini dimulai sejak tahun 2003 seiring dengan disahkannya UU Nomor 18 Tahun 2003 tentang Advokat.

Dalam rangka menyiapkan advokat yang profesional dan memiliki kompetensi di bidang hukum maka sesuai dengan amanat UU Nomor 18 Tahun 2003 setiap calon advokat wajib mengikuti pendidikan khusus profesi advokat yang dilaksanakan oleh organisasi advokat. Undang-Undang Advokat tersebut mengamanatkan bahwa salah satu syarat menjadi Advokat adalah dengan mengikuti pendidikan khusus profesi advokat dan lulus ujian advokat. Dengan mempertimbangkan bahwa saat ini organisasi advokat bukan lembaga penyelenggara pendidikan sebagaimana dimaksud dalam UU No. 20 Tahun 2003 tentang Sistem Pendidikan Nasional, maka salah satu Organisasi Pendiri PERADI bersama dengan lembaga penyelenggara pendidikan dapat menyelenggarakan Pendidikan Khusus Profesi Advokat (PKPA).

Berdasarkan Peraturan Peradi Nomor 3 Tahun 2006 tentang Penyelenggaraan Program Khusus Profesi Advokat dinyatakan bahwa setiap Lembaga Pendidikan (Hukum) yang akan menyelenggarakan PKPA, maka disyaratkan untuk melakukan Kerjasama terlebih dahulu dengan Peradi (Pasal 3).

Terkait dengan hal tersebut, sejumlah Fakultas Hukum dalam mendesain Continuing Legal Education (CLE), ada yang dijalankan secara integral dalam kurikulum Kampus dan sebagian besar lainnya dibuat secara terpisah dan tidak memiliki muatan kredit (SKS). 
Di Fakultas Hukum UII (2009) misalnya, CLE dirancang secara terpisah dengan kurikulum, namun masih saling bersinergi. Bagi mahasiswa yang akan mengikuti program-program CLE yang ada di Pusdiklat Laboratorium FH UII disyaratkan terlebih dahulu menempuh Mata Kuliah Kemahiran Hukum (MKKH) yang bersifat wajib antara lain:

a. Mata Kuliah Praktik Peradilan (3 sks)

b. Mata Kuliah Penyusunan Peraturan Perundang-undangan (2 sks)

c. Mata Kuliah Penyusunan Kontrak (2 sks)

d. Mata Kuliah Keadvokatan (2 sks) Menurut Eko Rial Nugroho (Wawancara, 10/9/2015), Pusdiklat Laboratorium FH UII mempunyai tugas untuk mempersiapkan dan mengelola MKKH sebagaimana di atas yang bertujuan untuk memberikan bekal yang cukup bagi mahasiswa, sehingga nantinya mahasiswa tidak hanya mahir dalam teori akan tetapi juga terampil dalam praktek. Adapun kewajiban lainnya adalah mengadakan pelatihan-pelatihan yang dibutuhkan mahasiswa sesuai dengan kebutuhan dunia kerja di bidang hukum. Pelatihan-pelatihan hukum sebagai program Pendidikan Lanjutan (CLE) yang dibutuhkan mahasiswa Fakultas Hukum Universitas Islam Indonesia adalah sebagai berikut:

1. Contract Drafting Nominate dan Inominate

Dalam pelatihan ini yang menjadi kajian atau materi pelatihannya antara lain adalah sebagai berikut:
a. Perjanjian jual-beli
b. Perjanjian sewa-menyewa
c. MoU dan Joint Venture Agreement
d. Francise
e. Pelatihan kontrak-kontrak lainnya

2. Legal Opinion

Dalam pelatihan ini ruang lingkup pelatihannya adalah bagaimana peserta diajarkan bagaimana peserta memiliki keterampilan dalam:
a. Membuat kronologi kasus dan mengidentifikasi masalah hukum
b. Penelususran bahan hukum
c. Teknik analisis

\section{d. Kesimpulan (pendapat hukum)}

3. Pendaftara dan Pengurusan Hak-Hak atas Tanah

Dalam pelatihan ini yang menjadi materinya adalah sebagai berikut:
a. Pendaftaran Tanah
b. Pemeliharaan data atas terjadinya peralihan ha katas tanah
c. Proses pemberian hak atas tanah
d. Proses pengurusan hak atas tanah

4. Hak atas Kekayaan Intelektual

Ruang lingkup materi pelatihan ini adalah sebagai berikut:

a. Teknik dan strategi pendaftaran hak merk

b. Teknik dan strategi pendaftaran hak cipta

c. Teknik dan strategi pendaftaran desain industry

d. Teknik dan strategi pendaftaran paten

e. Teknik dan strategi penyusunan draft lisensi HAKI

5. Penyusunan Peraturan Perundangundangan (Legal Drafting)

Dalam pelatihan ini materi yang diberikan kepada peserta pelatihan adalah sebagai berikut:

a. Teknik dan strategi penyusunan naskah Akademik

b. Teknik dan strategi penyusunan norma hukum dan pembuatan peraturan perundang-undangan

c. Teknik dan strategi penyusunan pidato penghantaran dan jawaban

d. Sosialisasi dan evaluasi peraturan dan teknik penyusunan perubahan peraturan perundang-undangan.

Berdasarkan sejumlah program CLE yang dikembangkan oleh Pusdiklat Laboratorium FH UII tersebut, semestinya Fakultas Hukum UNNES juga mampu menyelenggarakannya. Hal ini didasarkan pada data yang ada bahwa dari sisi tenaga pengajar di Fakultas Hukum UNNES terdapat beberapa dosen yang memiliki latar belakang kenotariatan. Hal ini menjadi modal yang berharga dalam pengayaan program-program CLE di Fakultas Hukum UNNES terutama menyangkut program-program training yang terkait dengan 
kontrak-kontrak hukum dan pertanahan.

Selain itu, secara infrastruktur juga sudah cukup memadai. Hanya saja, jika di Fakultas Hukum UII keberadaan infrastruktur pendukung program-program CLE bersifat integral di Pusdiklat Laboratoriumnya, di Fakultas Hukum UNNES keberadaannya terpisah-pisah dalam beberapa gugus, seperti: gugus $\mathrm{PKL}$, gugus $\mathrm{PKBH}$, Laboratorium, dan Kemasyarakatan. Kelemahnnya dalam model struktur gugus-gugus tersebut adalah kurang terorganisirnya antara program satu gugus dengan gugus lainnya, sehingga sinergisitas fungsional kegiatannya juga tidak begitu terlihat. Padahal sejatinya, seperti kegiatan PKL akan lebih baik persiapannya jika didahului dengan training-training yang relevan dengan kebutuhan pada saat pemagangan berlangsung, sehingga mahasiswa yang melakukan pemagangan memiliki cukup bekal pengetahuan dan keterampilan, dan di tempat mereka magang bisa cepat beradaptasi dengan pekerjaan yang diberikan kepada mereka. Sebab, jika mereka tidak memiliki bekal yang memadai dalam pemagangan, maka akan agak lama bisa beradaptasi.

Selain itu, pihak mitra yang menjadi tempat magang biasanya tidak punya cukup waktu untuk mengajari mereka mengenai pekerjaan-pekerjaan teknis yang mesti dikerjakan mahasiswa pada saat magang. Oleh sebab itu, penting untuk mempersiapkan mahasiswa sebelum magang.

\section{Analisis Faktor-Faktor Pendukung CLE}

Sebagaimana telah dijelaskan sebelumnya, bahwa berdasarkan data penelitian ini responden secara umum membutuhkan program pendidikan lanjutan (CLE) guna menyiapkan diri memasuki dunia kerja. Data penelitian ini menunjukkan bahwa mayoritas pilihan profesi karir di bidang hukum yang ingin mereka harapkan adalah sebagai praktisi hukum.

Dalam kaitan itu, profesi berbeda dengan pekerjaan pada umumnya. Diantara para sarjana belum ada kata sepakat mengenai batasan sebuah profesi. Hal ini terutama disebabkan oleh belum adanya suatu standar yang disepakati umum mengenai pekerjaan atau tugas yang bagaimanakah yang dikatakan dengan profesi tersebut. Sebuah profesi terdiri dari sekelompok terbatas orang-orang yang memiliki keahlian khusus dan dengan keahlian itu mereka dapat melakukan fungsinya di dalam masyarakat dengan lebih baik dibandingkan dengan warga masyarakat lain pada umumnya (Wahyono, 2012).

Sebuah profesi adalah sebutan atau jabatan dimana orang yang menyandangnya memiliki pengetahuan khusus yang diperolehnya melalui latihan atau training atau sejumlah pengalaman lain atau mungkin diperoleh sekaligus kedua-duanya. Penyandang profesi dapat membimbing atau memberi nasihat dan saran atau juga melayani orang lain dalam bidang-nya sendiri (Wahyono, 2012).

Jika dilihat dalam kamus besar bahasa Indonesia (2008) dijelaskan pengertian profesi adalah pekerjaan dengan keahlian khusus sebagai mata pencaharian. Sedangkan menurut komarudin profesi ialah suatu jenis pekerjaan yang karena sifatnya menuntut pengetahuan yang tinggi, khusus dan latihan yang istimewa. Sedangkan menurut Liliana Tedjosaputro sebagaimana dikutip Nita Wahyono (2008) agar suatu lapangan pekerjaan bisa dikatakan profesi diperlukan beberapa syarat sebagai berikut:

1. Pengetahuan

2. Penerapan kehalian

3. Tanggung jawab social

4. Self control

5. Pengakuan oleh masyarakat. Adapun ciri-ciri khas dari suatu Profesi adalah sebagai berikut (Wahyono, 2012):

1. Suatu bidang yang terorganisasi dari materi intelektual yang terus menerus berkembang dan diperluas.

2. Suatu teknik intelektual

3. Penerapan praktis dari teknik intelektual pada urusan praktis.

4. Suatu periode panjang untuk pelatihan dan sertifikasi.

5. Beberapa standar dan pernyataan tentang etika profesi yang dapat diselenggarakan.

6. Kemampuan memberi kepemimpinan pada profesi sendiri

7. Asosiasi anggota profesi yang akrab 
dengan komunikasi yang erat antar anggota.

8. Pengakuan sebagai profesi.

9. Perhatian yang professional dalam pekerjaan profesi dan adanya rasa bertanggungjawab.

10. Hubungan yang erat dengan profesi lain

Berdasarkan ketentuan di atas, maka profesi hukum merupakan salah satu dari sekian profesi lain misalnya, profesi dokter, akuntan dan lain-lain. Profesi hukum merupakan ciri yang tersendiri karena profesi ini sangat bersentuhan langsung dengan manusia atau klien, dalam profesi hukum adalah suatu hal yang menarik karena dalam keadaan sekarang banyak terjadi pelanggaran hak asasi manusia (Wahyono, 2012).

Pada dasarnya Profesi Hukum/Imuan Hukum dan Praktisi Hukum mempunyai arti yang tidak jauh berbeda dan dapat pula diartikan sama, menurut bahasa praktisi adalah pegiat, pekerja, atau pelaku.[3] Jadi profesi hukum/ Ilmuan Hukum dan atau Praktisi Hukum adalah mereka yang bekerja, dan melakukan kegiatan dibidang hukum sebagai mata pencaharian.

Profesi Hukum mempunyai keterkaitan dengan bidang hukum yang terdapat dalam Negara RI, profesi hukum meliputi (Supriadi, 2006):
a. hakim
b. penasihat hukum (Advokat, Pengacara)
c. notaries
d. jaksa
e. polisi

Profesi hukum merupakan salah satu profesi yang menuntut pemenuhan nilai moral dan pengemangannnya. Nilai moral itu merupakan kekuatan yang mengarahkan dan mendasari perbuatan luhur. Setiap professional dituntut untuk memiliki nilai moral yang kuat. Dalam profesi hukum ada lima criteria sebagai berikut (Supriadi, 2006:19-20).

1. Kejujuran adalah dasar utama, tanpa kejujuran professional hukum mengingkari profesinya, sehinggga menjadikannya munafik. Dalam kejujuran terdapat dua sikap yaitu terbuka dan sikap wajar.
2. Autentik artinya menghayati dan menunjukan diri sesuai dengan kasliannya, kepribadian yang sebenarnya. Autentik professional hukum antara lain :

a. Tidak menyalah gunakan wewenang.

b. Tidak melakukan peruatan yang merendahkan martabat.

c. Mendahulukan kepentingan klien.

d. Berani berinisiatif dan berbuat sendiri dengan bijaksana.

e. Tidak mengisolasi diri dari pergaulan.

3. Bertanggung jawab dalam melaksanakan tugasnya artinya :

a. Kesediaan melakukan dengan sebaik mungkin tugas apa saja yang termasuk lingkup profesinya.

b. Bertindak professional tanpa membedakan perkara bayaran dan perkara cuma-cima

4. Kemandirian moral, artinya tidak mudah terpengaruh atau tidak mudah mengikuti pandangan moral yang terjadi di sekitarnya, melainkan membentuk penilaian sendiri.

5. Keberanian moral, artinya adalah kestiaan terhadap suatu hati nurani yang menyatakan kesediaan untuk menaggung resiko konflik.

Melihat strategisnya profesi hukum tersebut, maka penyiapan sumber daya manusia untuk memenuhi kualifikasi professional dalam bidang hukum, maka diperlukan proses-proses pendidikan yang serius. Dalam konteks inilah maka CLE menjadi sarana yang paling memungkinkan dilakukan oleh Fakultas Hukum UNNES. Namun demikia, berdasarkan data penelitian ini, untuk mencapai keinginan tersebut diperlukan kesiapan-kesiapan yang komprehensif, baik dari aspek SDM maupun sarana dan prasarana pendukungnya.

Data ini menunjukkan bahwa dalam mendukung penguatan skill mahasiswa melalui program-program CLE sebagaimana telah diuraikan di atas, maka ada sejumlah faktor pendukung yang perlu diperhatikan. Pertama, kegiatan pemagangan mahasiswa disesuaikan dengan kebutuhan mahasiswa (37\%). Dalam konteks ini, gugus PKL Fakultas Hukum dapat bersinergi dengan laboratorium 
hukum atau unit minat bakat mahasiswa utuk melakukan pemetaan terhadap kebutuhan pemagangan mahasiswa. Pemetaan pemnitaan bisa dilakukan dengan strategi survei atau metode-metode lainnya yang dianggap representative.

Kedua, faktor pendukung kesuksesan program-program CLE ada dengan cara penguatan laboratorium hukum yang mengintegrasikan berbagai program CLE, apakah akan meniru model pusdiklat laboratorium Fakultas Hukum UII atau melakukan revitalisasi dari model yang ada dengan inovas-inovasi yang sinergis, sehingga program-program tersebut dapat berjalan dan terukur dengan jelas.

Ketiga, adalah porsi atau komposisi tenaga pengajar untuk program-program CLE perlu melibatkan banyak praktisi hukum, sehingga mereka tidak hanya mengulang pelajaran teori yang disampaikan dosen, tetapi ada nilai-nilai ekperimental yang dapat dibagikan kepada mahasiswa.

Selain faktor-faktor sebagaimana disebutkan di atas, menurut Harkristuti Harkrisnowo (2003) ada faktor-faktor lainnya yang bisa mendukung kualitas lulusan Fakultas Hukum. Dalam bidang pengajaran, peningkatan mutu fakultas hukum dan produknya, yakni lulusan fakultas hukum tidak akan dapat diraih tanpa adanya dukungan yang mendasar dari beberapa faktor yang signifikan, yakni: Pertama, Mahasiswa yang bermutu. Dalam kaitan ini terdapat tiga hal yang terkait, yakni:

a. Proses pendidikan yang terjadi di tingkat sekolah menengah akan sangat banyak menentukan mutu mahasiswa yang masuk ke dalam universitas.

b. Proses seleksi bagi calon mahasiswa yang akan masuk ke dalam perguruan tinggi sangat bervariasi, yang pada gilirannya menghasilkan variasi mutu mahasiswa. Sebagai akibatnya, mahasiswa berprestasi sajalah yang dapat masuk ke dalam fakultas hukum yang bermutu tinggi.

c. Rendahnya kebiasaan mahasiswa untuk mempersiapkan diri sebelum perkuliahan melalui membaca dan berdiskusi ternyata memiliki dampak yang sangat signifikan dalam output proses belajar-mengajar.

Kedua, Metode pengajaran. Sudah tidak lagi masanya untuk memberikan materi pada mahasiswa secara one-way communication, karena justru di lembaga pendidikan tinggilah mahasiswa didorong untuk dapat berpikir sendiri secara kritis, dan bukannya disuapi belaka. Metode pengajaran dua arah yang mendorong mahasiswa untuk mengekspresikan pikirannya di dalam kelas, dalam banyak hal belum sepenuhnya diadaptasi oleh mahasiswa, utamanya mahasiswa semester awal.

Ketiga, Tenaga pengajar yang handal dalam materi maupun metode. Pendidikan hukum lanjutan bergelar (S1 dan S2) pada masa depan akan merupakan conditio sine qua non bagi para pengajar universitas. Keterbatasan pengajar yang tidak pernah memperoleh pendidikan mengenai cara mendidik, selayaknya diatasi dengan lebih banyak kursus singkat, diskusi dan belajar dari pengalaman baik diri sendiri maupun orang lain.

Keempat, Kekinian materi perkuliahan. Materi perkuliahan yang disampaikan memang tetap harus mengacu pada pustaka klasik sampai dengan tingkat tertentu. Akan tetapi, kekinian materi tetap harus diperhatikan oleh para pengajar agar mahasiswa juga menerima informasi yang up to date. Kcenderungan pengajar untuk memakai materi yang sama dari tahun ke tahun (doktrin, hukum positif, dan kasus) harus diupayakan untuk diubah.

Ketersediaan perpustakaan yang selalu ditingkatkan baik mutu pelayanan maupun koleksinya. Salah satu pilar dalam pendidikan tinggi adalah koleksi pustaka yang memadai. Tanpa adanya perpustakaan yang mampu menampung kebutuhan dan minat mahasiswa, sulit membayangkan dapat berkembangnya pemikiran mahasiswa dan juga pengajar.

Mengingat information technology sudah demikian berkembangnya, setiap universitas dituntut untuk menyediakan sarana tersebut bagi civitas academica untuk pengembangan ilmu dan pengetahuan yang lebih tinggi. 


\section{Simpulan}

Berdasarkan hasil analisis data penelitian ini sebagaimana telah diuraikan sebelumnya, maka dapat disimpulkan sebagai berikut. Pertama, Program Pendidikan Lanjutan (Continuing Legal Education) dibutuhkan oleh mahasiswa Fakultas Hukum UNNES dikarenakan sistem perkuliahan yang ada selama ini masih dominan teoretis, sehingga mahasiswa merasa kurang pengetahuannya dalam konteks praktis. Hal ini juga didukung fakta bahwa para pengampu Mata Kuliah Kemahiran Hukum juga masih sedikit yang diampu oleh praktisi hukum yang diharapkan bisa membagi pengalaman-pengalaman empiris mereka kepada mahaiswa. Alasan lainnya mengenai pentingnya CLE bagi mahasiswa adalah karena Laboratorium Fakultas Hukum UNNES masih belum memberikan programprogram penguatan skill mahasiswa secara terpadu dan sistemik, sehingga keterampilan hukum mahasiswa masih belum maksimal.

Kedua, ada sejumlah program pendidikan lanjutan yang dibutuhkan mahasiswa dalam membekali mereka memasuki dunia kerja, yakni: pemagangan yang disesuaikan dengan kebutuhan mahasiswa. Selanjutnya adalah training perancangan kontrak-kontrak hukum yang bersifat praktis dalam berbagai model, seperti kontrak bisnis, perjanjian-perjanjian, jual-beli tanah dan lain sebagainya. Selain itu, training legal drafting juga dianggap penting dimasukkan sebagai program CLE di bawah koordinasi laboratorium hukum.

Ketiga, faktor-faktor pendukung dalam program pendidikan lanjutan (CLE) adalah kualifikasi pengajar Mata Kuliah Kemahiran Hukum yang perlu diperbanyak dari unsur praktisi. Selain itu, dukungan sarana dan prasarana laboratorium yang terintegrasi dengan program-program lainnya yang sudah ada di Fakultas Hukum UNNES. Sinegisitas program dan penguatan kewenangan laboratorium merupakan sebuah keniscayaan dalam pelaksanaan program pendidikan lanjutan yang dibutuhkan oleh mahasiswa. Model pengelolaan laboratorium hukum yang ada sekarang tentu masih belum cukup memadai.

Berdasarkan simpulan di atas, maka dapat direkomendasikan sebagai berikut.
Pertama, Program Pendidikan Lanjutan sangat mendesak direalisasikan di Fakultas Hukum UNNES. Hal ini dikarenakan persaingan di pasar kerja sangat kompetitif, sehingga alumni Fakultas Hukum UNNES tidak saja memiliki kemampuan teoretis, tetapi juga kemampuan skill hukum juga mutlak dibutuhkan. Kedua, perlu dilakukan revitalisasi laboratorium hukum yang ada saat ini. Model pengembangannya bisa dilakukan dengan model comparative studi dengan laboratorium hukum yang sudah eksis di FakultasFakultas Hukum lainnya di Indonesia.

\section{Daftar Pustaka}

BusinessDictionary.com, Continuing Education Program, <http://www.businessdictionary.com/ definition/continuing-education-program. html>, (diakses, 11 Mei 2015).

Cahrlie, 2009. Hasi Survey Persepsi Dunia Kerja terhadap Lulusan Perguruan Tinggi S1, <http:// climbingday.blogspot.com/2009/03/hasil-survey-persepsi-dunia-kerja.html>, (diakses 11 Mei 2015).

Gulo, W. 2012. Metodologi Penelitian, Jakarta: Grasindo.

Harkrisnowo, H. 2003. Pendidikan Tinggi Hukum dalam Sistem Peradilan Terpadu, dalam < http://www. hukumonline.com/berita/baca/hol7255/pendidikan-tinggi-hukum-dalam-sistem-peradilanterpadu>, diakses tanggal 13 November 2015.

Hukumonline, 2003. Mimpi Sarjana Hukum Jadi Pengacara, <http://www.hukumonline.com/berita/ baca/hol8367/mimpi-sarjana-hukum-jadi-pengacara >, (diakses 11 Mei 2015).

Hukumonline, 2014. Lulusan Fakultas Hukum Harus "5 Bisa'. <http://www.hukumonline.com/berita/ baca/lt542c0fc2a848c/lulusan-fakultas-hukumharus-5-bisa >, (diakses 11 Mei 2015).

Iskandar, Pranoto. 2012. Memahami Hukum Indonesia, Cianjur: IMR Press.

Juwono, Hikmahanto. 2003. Memikirkan Kembali Sistem Pendidikan Hukum Indonesia, Jurnal Jentera, Edisi Khusus, Pusat Studi Hukum dan Kebijakan Indonesia, Jakarta.

Kurniawan, Tony, Menjual Kualitas, Bukan Gelar, <http://www.surveyone.co.id/download/Survei_sekolah_MM.pdf>, (diakses 11 Mei 2015).

Musnandar, Aris, 2014. Antara Dunia Pendidikan dan Dunia Kerja. <http://www.umm.ac.id/id/detail- 
199-antara-dunia-pendidikan-dan-dunia-kerjaopini-umm.html>, (diakses 11 Mei 2015).

Rahardjo, Satjipto. 2009. Pendidikan Hukum sebagai Pendidikan Manusia, Jogjakarta: Genta Publishing.

Sahlan, Sartono. "Pilihan Profesi Hukum Mahasiswa Dalam Pengembangan Kurikulum Fakultas Hukum", Pandecta: Research Law Journal, Vol. 8 Nomor 2 Tahun 2013.

Seran, Alexander. 1999. Moral Politik Hukum, Jakarta: Penerbit Obor.

Sihombing, Uli Parulian, 2009. Mengajarkan Hukum yang Berkeadilan: Cetak Biru Pembaruan Pendidikan Hukum Berbasis Keadilan Sosial, Jakarta: The Indonesian Legal Resources Center (ILRC).

Supriadi, 2006. Etika dan Tanggung Jawab Profesi Hukum di Indonesia, Jakarta : Sinar Grafika.

Tim Redaksi Pusat Bahasa Nasional, 2008. Tesaurus Pusat Bahasa Nasional Jakarta: Departemen Pendidikan Nasional.

Wahyono, Nita. 2012. Etika Profesi Hukum "Profesi Hukum / Ilmuan Hukum dan Praktisi Hukum \& Kode Etik Jaksa dan Dewan Kehormatan Jaksa, dalam <http://nitawahyono.blogspot.co.id/2012/10/ etika-profesi-hukum-profesi-hukum.html> diakses tanggal 13 November 2015.

Wignkosoebroto, Soetandyo. 2009. Perkembangan Hukum Nasional dan Pendidikan Hukum di Indonesia pada Era Pasca Kolonial, <http:/www. huma.or.id/document/1.03.Analisa Hukum/ Perkembangan Hukum Nasional dan Pendidikan Hukum di Indonesia pada Era Pasca Kolonial_Soetandyo.pdf >. 